\title{
A Continent Divided
}

\author{
Silvio Pons
}

\section{Stalin and the Fate of Europe: The Postwar Struggle for Sovereignty \\ by Norman Naimark}

The Belknap Press, 368 pp., \$29.95.

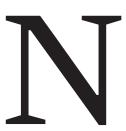

ORMAN NAIMARK is one of the foremost authorities on Soviet history and the reign of Joseph Stalin. In Naimark's latest work, Stalin and the Fate of Europe: The Postwar Struggle for Sovereignty, he turns his attention to Stalin's foreign policy objectives in Europe during the early postwar period. The book is the culmination of many years of research and is destined to become a point of reference for many years to come.

Naimark uses seven case studies to demonstrate the complex and often contradictory nature of Stalin's strategic thinking after the Second World War: the Danish island of Bornholm; Albania; Finland; Italy in 1948; the Soviet bloc in Berlin between 1948 and 1949; Poland between the end of the war and 1949; and Austria before the independence treaty of 1955. These examples also serve to illustrate how local leaders and governments were more influential in shaping the course of Cold War history than has generally been assumed by historians.

The political intricacies of postwar Europe, Naimark believes, can only be understood by a careful examination of the interactions between the major powers and smaller nations. While such an approach has been applied successfully in studies of Western Europe, ${ }^{1}$ Naimark shows it can also be useful when considering the countries under Soviet influence. "Against the backdrop of the war," he observes, "the new leaders of Europe shared a commitment to the sovereignty and independence of their countries as well as to the rebuilding of their nation's economies and societies." Although some of these leaders were resigned to the fate of their countries remaining tied to the major powers,

even the vast majority of the communists who had entered politics during the anti-German partisan movement or in the campaign for the "new democracies" after the war, were committed to ensuring their country's ability to make their own decisions about the future, despite the constraints foisted upon them by foreign occupation forces. ${ }^{2}$
"Postwar Europe," Naimark remarks, "was no place for utopian fantasies." Throughout the continent, but especially in Central and Eastern Europe, a deep mark had been left by the war. Amid the destruction and upheaval, a lingering sense of unease prevailed during the early postwar years. Tensions between the major powers were never far from the surface and often emerged as a result of legitimate, albeit conflicting, security interests. Stalin's realpolitik was only one factor in this broader political context. It is these complexities that Naimark has in mind when he argues that, "there was greater fluidity and openness to postwar settlement in Europe than is often assumed both in the historiography and in public memory."3

In April 1945, Stalin imparted to the Yugoslav communist leader Milovan Đilas his vision of postwar Europe: each of the victors would impose their own social system on the territories that it conquered. Stalin's words, as Đilas recounted them in the early 1960s, captured the imaginations of historians, but they also served to reinforce a commonly held, retrospective view of the Cold War in Europe. A more detailed survey, such as that undertaken by Naimark, shows that the true picture is a good deal more complex and that Stalin's postwar vision was not always realized. Indeed, the presence of the Red Army did not lead to the Soviet system becoming established in Austria or Finland, or even in Czechoslovakia, where the Soviets withdrew and let free elections take place. In each case, Stalin's shifting strategies were also shaped by local leaders and governments who were anything but passive participants.

The interpretation that Naimark advances in Stalin and the Fate of Europe is not entirely new. Some of these arguments have been outlined in his prior writings. ${ }^{4}$ The difference with this new account is the wealth of evidence that Naimark has assembled in support of his views. He rejects outright the notion that Stalin had an immediate plan to sovietize Europe. Instead, Naimark argues that Stalin was more sensitive to the problem of the Soviet Union's security. His main concerns were to prevent a revival of German nationalism and to turn Eastern Europe into a Soviet security zone that would control Warsaw, Helsinki, and Bucharest. Rather than fomenting revolutions, 
he was more interested in creating spheres of influence. Stalin likely saw socialism as something to be accomplished through a gradual process. He viewed the mixed economies and antifascist democracies in Eastern Europe as providing the basis from which socialism would emerge and that it might subsequently spread to Italy, Greece, and even Great Britain. Between 1944 and 1946, he repeatedly spoke of a "new type of democracy." Naimark argues that in some cases, such as Stalin's appeals to Polish communists, these claims should be given proper consideration.

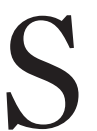
ome of the national case studies offered by Naimark have already been the subject of numerous books and papers. Nonetheless, he is still able to shed fresh light on the postwar histories of these countries by highlighting interconnections and parallels that extend beyond the usual focus on sovietization. This is particularly true for Naimark's analysis of the transition that occurred in 1948 from a postwar Europe subject to spheres of influence to one firmly divided into political and military blocs.

Considerations of Finland's postwar fate, for example, have often tended to focus on its singularity. In chapter 3 , Naimark examines the Finnish experience in a different light, that is, not only as the sole non-sovietized country under Soviet influence, but also as a case of compromise reached between local leaders and Stalin. Finnish pro-Soviet neutrality was largely the result of a strategy pursued by President Juho Kusti Paasikivi. He sought to guarantee the sovereignty of Finland by accepting communist involvement in domestic politics, albeit in a marginal role. Stalin considered such a compromise to be more than acceptable and contented himself with limiting the country's autonomy in foreign policy.

The coup d'état that took place in Prague during late February 1948 led to widespread fears among Finns that their country would meet a similar fate. This was especially true in the lead-up to the signing of the Finno-Soviet Friendship Treaty on April 6, 1948. The Finnish military were secretly mobilized and precautionary measures taken, but as Naimark notes, "[T]here is no evidence that the Soviets thought a coup would work in their interests in Finland." ${ }^{5}$

The Prague coup was thought to pose an even greater threat in Austria, at least in the minds of the local population. Despite a Soviet military presence, such an option was not advanced there either. The Austrian president Karl Renner and his Social Democratic Workers' Partythe subjects of chapter 7-were well aware of the local unpopularity of the Soviets and communism. With this in mind, they cautiously embarked on long negotiations for a treaty, which would not be concluded until after Stalin's death. Stalin's approach to Austria wavered during negotiations and reflected his indecision over how much autonomy to allow the country.
MOng the CASE StUdies examined by Naimark, the Italian elections of 1948-the topic of chapter
1 4-are the only example involving Stalin's policies toward a country in the Western sphere. Although the postwar strategic context in Italy was complicated by the presence of the United States, Naimark nonetheless finds similar dynamics at play between the Soviets and the local communists. The political circumstances in Italy at the end of the war made it a crucial test of the emerging postwar relationship between the great powers. After the Allies landed in Sicily, the fascist regime fell on July 25,1943 . An armistice was announced which divided the country into two parts. In the north, a neofascist Italian Social Republic was put in place under German supervision and led by Benito Mussolini. In the south, under Allied protection, the government of Pietro Badoglio took charge. Marginalized by the armistice, the Soviet Union reacted by recognizing the Badoglio government in March 1944-a move that laid the groundwork for the Italian Communist Party leader Palmiro Togliatti to make what became known as the Salerno turn. He announced that the communists were willing to disavow armed struggle and support a democratic government. Any final decision concerning the choice between the monarch and a new republic, Togliatti suggested, should be postponed until the end of the war. This approach also ensured the emergence of an institutionally legitimized mass communist party in the western sphere of influence.

Togliatti's pragmatic approach may have prevented a revolution in the short term, but underlying tensions escalated significantly during the Cold War. Fed by mass mobilization and inflammatory propaganda from both sides, the general elections of April 1948 were especially contentious. Alcide De Gasperi led the majority centrist party, the Christian Democrats, with the support of the United States and the Catholic church. Their main opponents were a leftist alliance of communist and socialist parties, the Popular Democratic Front. In the months leading up to the election, protests against American aid that were inspired by the formation of the Cominform seemed to presage an insurrection, or even a civil war. George Kennan, an architect of the Marshall Plan, argued that civil war and a military division of Italy would be necessary to prevent the Popular Democratic Front from winning the election. James Dunn, the US Ambassador to Italy, predicted that the communists would start an armed conflict if they were defeated. And the Italian Communist Party, in turn, feared that, if they won, Washington would support a coup d'état. But the election outcome, which bore no hint of fraud or subterfuge, diffused the tension. The Christian Democrats comfortably defeated the Popular Democratic Front, winning almost half of the popular vote.

Before the election, Togliatti advised Moscow against pursuing an insurgency, even though many in his party 
may have wished for it, and Josip Broz Tito, the prime minister of Yugoslavia, had promised to support it. Rather than just asking for Stalin's position, Togliatti made his own case that an Italian civil war would have uncontrollable international consequences and might lead to a new world war. He announced that he alone would make the final decision about an uprising. Stalin approved Togliatti's plan and advised him not to follow the Yugoslavs' suggestions. This approach was maintained even when tensions rose after an assassination attempt on Togliatti in July 1948. Party leaders did not call for public mobilization and Togliatti appealed for calm from his hospital bed. Once again, Moscow agreed. The Italian elections were a significant test of the Western Bloc, and the leadership in Washington viewed the results as the beginning of a new phase in the fight against communist influence. But these elections also demonstrated the self-restraint of local communists. Togliatti, notes Naimark, can be considered as a leader "pursuing Italian sovereignty and building Italian democracy, despite his unquestionable loyalty to Moscow."

$\mathrm{T}$

HE BERLIN BLOCKADE began shortly after the Italian elections. In chapter 5, Naimark analyzes an aspect of that event that historians have tended to overlook, namely the role that the blockade played in changing Soviet policies toward Germany. Archival evidence shows that, when Stalin initiated the blockade, he did not consider the possibility that it might lead to a military conflict. His sole focus was on preventing the formation of a West German state. Stalin's conduct and strategy nonetheless remain opaque because the tension produced by the blockade did not favor such an outcomeall the more so since diplomatic contacts were suspended for about a year. According to Naimark, at the end of the war Stalin was against the idea of dividing Germany because the eastern portion was smaller and weaker in its industrial capacities. Instead, he would have preferred an outcome similar to the Finnish model: a united and neutral Germany, not necessarily sovietized, but largely subject to the influence of Moscow.

Stalin did not expect that the West, especially France and the United Kingdom, would defend an economically ravaged Germany, though this was precisely what they did with the Marshall Plan. It may have been aimed at dividing the Western allies, but as Naimark notes, "the blockade contributed to the building of the Atlantic Alliance." In effect, Stalin was pursuing contradictory policies. On the one hand, he pushed the German Communist Party to establish a government in the Soviet occupation zone at the end of 1948. On the other hand, even on the eve of the birth of West Germany in 1949, he continued to insist on his desire for a united Germany.

On September 9, 1948, the mayor of West Berlin, Ernst Reuter, gave a speech that Naimark points to as "one of the most dramatic-and effective-of the early Cold War period." ${ }^{8}$ Reuter appealed to the world to look to Berlin and its population as defenders of universal freedoms. He refused to abandon the city to the Soviet zone, and called for West Berlin to be included in West Germany. Naimark describes in detail how Reuter was able to influence General Lucius Clay and the American administration, ensuring the resistance of the Berliners and the success of the airlift that finally thwarted Stalin.

\section{$\mathrm{T}$} HROUGHOUT THIS PERIOD, national sovereignty within the communist movement proved difficult to manage from Moscow. This was particularly true in Poland. In chapter 6, Naimark explores how the postwar leader Władysław Gomułka pursued Polish sovereignty until international circumstances made it impractical. As early as 1945, Gomulka complained to Moscow that the Red Army's conduct in Poland was making the communists extremely unpopular. Despite his protestations, Gomulka's primary concern was that he wanted Poland to have a popular democracy that differed from the Soviet model. In a country which was predominantly rural, this meant that the countryside should not be collectivized, at least not for long. Stalin and Gomulka agreed on this point. The "Polish way to socialism," as Gomułka called it, would not be truly democratic given Stalin and Gomulka's shared objective of establishing Communist Party rule. But neither would it be a "dictatorship of the proletariat," as Stalin himself proposed in May $1946 .{ }^{9}$

Gomułka insisted on the need for Poland to retain some degree of autonomy, in spite of opposition from communist hardliners such as Jakub Berman and Bolesław Bierut. In late 1947, the creation of the Cominform had implications for the relative independence enjoyed by the Polish party. The initial targets of the Cominform may have been Western Communists, but Gomułka came to realize that the postwar compromise on Poland's sovereignty was in danger. He also probably felt deceived by the Soviets, who had presented the Cominform as much more benign. For this reason, he avoided the frontlines after hosting the Cominform's founding conference, a position reinforced by news of the break between Stalin and Tito. The discontent expressed by the Yugoslavs led Moscow to tighten its control over the countries of Central and Eastern Europe. One of the first targets was Gomulka. A dossier against his so-called "nationalist deviationism" was presented in Moscow in April 1948. In September, accusations were leveled at him during a Central Committee plenum.

Gomulka continued to defend his agenda by all possible means, even the most unscrupulous. He presented himself as the leader who would guarantee Poland's socialist and patriotic cause against the influence of the Jews and what he described as their "national nihilism." This argument appealed to Stalin's growing anti-Semitism, which had emerged from his campaign against cosmopolitanism. But 
this approach was only partially successful. At the end of 1948, Gomulka found himself on a collision course with the Soviet leader. Stalin proposed that Gomulka join the new leadership group of the United Polish Workers' Party, along with Bierut, Berman, and the minister of industry, Hilary Minc. Gomulka accepted at first, but then wrote a letter declining the request. This open defiance of Stalin sealed his fate. Gomulka was arrested in August 1951 and remained in prison without trial until the end of 1954. In the end, Poland was unable to reach a compromise with the Soviet Union, unlike Finland. But Naimark observes that, ultimately, "Gomulka can be seen as having won his struggle with Stalin, over what he saw as the related issues of the Jews in the Polish Party and the distinct Polish road to socialism."10 Gomulka later returned to power during the social and political crises of 1956.

$\mathrm{I}$

F ANYTHING IS TO BE criticized about Stalin and the Fate of Europe, it is that Naimark might have provided some further case studies. The plight of Czechoslovakia, which maintained a pluralist political system until 1948, would have been worthwhile to examine and might have provided another example of the dynamics by which sovereignty was affirmed and lost. The reverberations of the coup d'état in Prague also had a broader significance and were felt across Europe.

In his closing remarks, Naimark claims that, "the coming of the Cold War unquestionably influenced the fate of Europe in the immediate postwar years, but it was not as dominant a factor as many historians suggest," mainly because "the agency of Europeans mattered and mattered a lot." Even in the Soviet sphere, "the struggle was real, and there was little that was inevitable about the division of the continent in the immediate postwar period." This lesson, as the author points out, is significant for the memory of Europeans, because they ultimately won the fight for sovereignty. In the aftermath of European inte- gration and détente, the communist regimes ultimately collapsed and the European Union was born.

Translated and adapted from the Italian by the editors.

Silvio Pons is Professor of Contemporary History at the Scuola Normale Superiore in Pisa.

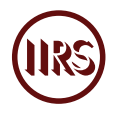

1. See, for example, Federico Romero, Storia della guerra fredda: L'ultimo conflitto per l'Europa (Turin: Einaudi, 2009).

2. Norman Naimark, Stalin and the Fate of Europe: The Postwar Struggle for Sovereignty (Cambridge: The Belknap Press of Harvard University Press, 2019), 21.

3. For a conventional narrative, see Anne Applebaum, Iron Curtain: The Crushing of Eastern Europe, 1944-1956 (New York: Knopf Doubleday, 2013). For a reconstruction covering a broader chronological arc, providing a reading of Sovietization as an inevitable product of the encounter between the Stalinist Soviet Union and Europe, see Timothy Snyder and Ray Brandon, eds., Stalin and Europe: Imitation and Domination (Oxford \& New York: Oxford University Press, 2014).

4. Norman Naimark, The Russians in Germany: A History of the Soviet Zone of Occupation, 1945-1949 (New Haven: Harvard University Press, 1995).

5. Naimark, Stalin and the Fate of Europe, 119.

6. Naimark, Stalin and the Fate of Europe, 268.

7. Naimark, Stalin and the Fate of Europe, 193.

8. Naimark, Stalin and the Fate of Europe, 186.

9. Naimark, Stalin and the Fate of Europe, 205.

10. Naimark, Stalin and the Fate of Europe, 229.

11. Naimark, Stalin and the Fate of Europe, 270-72.

DOI: $10.37282 / 991819.21 .31$ 